\title{
TEACHERS' PERFORMANCE IN RELATION TO TEACHING OF MOTOR SKILLS DURING LESSONS OF PHYSICAL EDUCATION
}

\author{
JANUSZ GAEECKI, LECH KURPETA, IGOR CIEŚLIŃSKI \\ Józef Piłsudski University of Physical Education in Warsaw, \\ Faculty of Physical Education and Sport in Biała Podlaska, \\ Department of Theory and Methods of Physical Education
}

\author{
Mailing address: Janusz Gałecki, Faculty of Physical Education and Sport, \\ Department of Theory and Methods of Physical Education, 2 Akademicka Street, 21-500 Biała Podlaska, \\ tel.: +48 83 3428700, fax: +48 83 3428800, e-mail: janusz.galecki@awf-bp.edu.pl
}

\begin{abstract}
Introduction. The aim of the study was to assess the teacher's performance during developing motor skills in students by physical education teachers. Results and findings from the assessment of preparatory, indicatory, control, correcting and pro-social activities are presented in the paper. Motivating and informing activities were assessed and reported in the first part of the study [1]. Material and methods. The study was conducted in 55 upper-secondary schools in the Lubelszczyzna province. Thirty female and 52 male teachers, representing all stages of the professional career, participated. Based on a pre-defined form used for the surveillance, data from 315 school classes was collected. Results. The data was analysed with respect to gender and the stage of professional career of the participants. Significant differences in the conduct of the subsequent activities were found between male and female teachers. Minor tendencies towards alterations were observed among individual stages of the career. Conclusions. In general, the studied teachers performed satisfactorily as regards students' motor skills' development, regardless their stage of professional career, and gender.
\end{abstract}

Key words: motor skills' teaching, teacher's activities, upper-secondary school students

\section{Introduction}

The issue of the fulfilling the task of teaching and providing students with optimal range of motor skills is among the core aims of school and physical education teachers. In the school practice, motor skills are nothing but specified exercises or motor tasks, most frequently regarding techniques of given sports. Weak effects of the development of motor skills may result from various origins, however in majority they origin from a lack of focused attitudes of teachers, and an accurate programme for fulfilling the task, which is to form a desirable task setting [2]. A focused performance will show to modify the initial situation to the final one and then such activities can be defined as performance. For instance, the performance of learning of the movement technique leads from a situation of no skill to skill, the performance of self-development of skills leads from the situation of low skill to the situation of high skill $[3,4]$. The achieved results frequently do not correspond with the preformulated goals, in similar manner as the real-life activities and programmes, and then we can talk about errors of the result and errors of the action [5]. Every performance may be divided into sub-performances, called operations, which, subsequently, decide of the structure of the action. The structures of the action may be analysed in categories of the objective (external), the subjective (modal), and the formal structures, respectively. The latter represents the linear (serial), the most basic structure, in which the result is achieved by a series of consecutive partitive tasks - operations. Operations, contrasted against motor tasks, are merely exercises, i.e. partitive tasks constituting the central task [3].

Contemporarily, it is more and more frequent claimed, that the effects of the performance of motor skills are dependent on the completion of the teachers' pedagogic activities and the conditions in which those activities take place. The characteristic feature of the teachers activities is that they are about leading the students' performance and about a specific co-operation with the students.

A pedagogic activity of a teacher is identified as their attitude and focusing on the achievement of a particular effect of a task performed by the students. The activities of students are, on the other hand, actions directed on accomplishing a task focused on a given result. It can be seen that a task, according to contemporary psychologists, is a pattern and a factor regulating those activities, which, in turn, may have a simple or a sophisticated characteristic. Complex tasks are those accomplished through simple tasks, which, in turn, influence the structure and effects of doing [5, 6].

Every pedagogic task, also the movement task, has a thematic (referring to the subject matter) component, addressing the question "what?", and the operative (functional) component, addressing the question "how?". Depending on the degree of difficulty of a motor task, we choose an appriopriate - easier or more difficult - way of teaching. The choice of a strategy of teaching is a function of, and emerges from, the completion of particular activities of both a teacher and a student. Among teachers' activities, preparatory, motivating, informing, indicatory, control, correcting, securing and pro-social ones may be distinguished $[5,7,8,9]$.

The effects of teaching of the motor skills are also dependent on the relationships between the teacher (the manager of the process) - student (receiver), and performer of the tasks proposed by the teacher. Frequently, such relationships take place 
in various styles of the educational authority of the teacher, and it typically is a particular style of acting of the teacher within the managing dealings. First studies to date on the styles of educational actions were conducted by White and Lippitt, who on that basis defined three styles of managing a group, namely the democratic, autocratic, and the free hand style, also called the liberal style, respectively. Presently, it is assumed that "pure" styles are not met in practice, which means that teachers' attitudes are placed between the democratic and autocratic styles. The liberal style is neglected, as the features of teacher's actions are lacking or insignificant in this particular style. Studies on the "productivity of the styles" have confirmed the higher effectiveness of the democratic managing over the autocratic and liberal ones. It also should be added that some studies claim that in the situations of hazard the autocratic management is more efficient [10]. Methods which activate students' reasoning, stress their independent working, initiative and invention, considerably improve results of teaching and educating. Applying of such methods is characteristic for the democratic style, which, according to Jankowski, is fully efficient as late as in the upper grades. Preschool- and schoolchildren of lower grades require the autocratic managing in its mild form, taking place in the form of so called benign autocracy. Such children need more external directives from the teacher, as they yet do not present the skills of self-control of their behaviour [11].

When analysing the above mentioned styles of managing, it can be assumed that the democratic style can give the student significant freedom of performing, but does not deprive the teacher from the control of the process of teaching and educating. The student is allowed to create their own solutions, and the teacher is more an advisor and a guide than an executor. The fact that the student is entrusted with the responsibility in terms of self-control and self-assessment of their advances, which makes him or her an active subject, and co-organiser of the process, gains a particular significance in the democratic style.

It might be assumed that the liberal style contains even greater educational opportunities than the democratic style. It appears, however, that the work effectiveness in the liberally managed groups is very low, an informal structure of command is usually formed, in which an informal leader directs the other students in the autocratic way. In a similar manner, the autocratic style does not lead to considerable effects in the educational work. Student groups, lead with this style, occasionally reach significant effects, but then it is achieved with a cost of forced obedience to the teacher's orders. The student is bereft from self-invention, which influences their work motivation. Executing of obedience, discipline and implicit performing of the teachers' orders, can often lead to anxiety, aggression, resignation or apathy in the student. Unfortunately, this style of educational actions has still a large body of advocates in the Polish school.

When considering the styles of managing a group, the issue of the effectiveness of rewards and punishments cannot be ignored, as many teachers assume that the value of punishment is far lower than the value of reward. Therefore, the styles of educational activity with the dominance of rewarding over punishing are more efficient. We can also underline the value of the "emotional warmth", emitted by the teachers during contacts with the students. In this case, it is the influence of the favourable and negative emotions for the student. Frequently, the so called nonverbal messages, such as smile, a friendly gesture, and so on, are assumed as the teacher's actions categorized as favourable or hostile. Such behaviours as coldness, lack of empathy, excessive strictness, diminish the effectiveness of teaching $[12,13]$.

The aim of the study was to identify in what extend the teachers utilized the educational actions and what style of the management of the group dominated during teaching of the motor skills at the physical education classes in the uppersecondary schools in the region of Lubelszczyzna.

\section{Material and methods}

The study was conducted in 55 upper-secondary schools of the Lubelskie voivodeship. Thirty female and 52 male teachers, representing all stages of the professional career, participated. The technique of observation was utilized, and within it the observation sheet designed at the Department of Theory and Methods of Physical Education, Faculty of Physical Education and Sport in Biała Podlaska, comprising a registry of actions, which should be undertaken by teachers in the process of teaching of movement skills. The observers' task was to take notes of those actions, which occurred during a lesson.

Overall, the study data was gathered from the observations of 315 classes of physical education, of which 126 (40\%) and $180(60 \%)$ were conducted by female and male teachers, respectively. Gender and stage of professional career were considered in the analysis of data.

\section{Results}

As regards the preparatory actions, teachers' attitudes and the style of conducting the lessons were assessed. It appears that the majority of lessons (98\%) was conducted in friendly and favourable atmosphere, with the most prominent results of the lessons conducted by female "qualified" (the middle step of professional career) and male "certified" (the upper step of the professional career) teachers (24\% and 36\%, respectively). A minor percentage of the lessons (2\%) was run in an unfriendly atmosphere, and that occurred mainly during the lessons conducted by teachers with the upper stage of career (tab. 1). The statistical analysis does not confirm any significant relationships as regards the atmosphere during the lessons and the analysed groups.

Table 1. Attitude of a teacher during teaching (in \% of lessons)

\begin{tabular}{|c|c|c|c|c|c|c|c|c|}
\hline \multirow{3}{*}{$\begin{array}{l}\text { Categories } \\
\text { of responses }\end{array}$} & \multirow{2}{*}{\multicolumn{3}{|c|}{$\begin{array}{c}\text { Female teachers* } \\
\text { Stage } \\
\text { of professional career }\end{array}$}} & \multirow{3}{*}{ Total } & \multirow{2}{*}{\multicolumn{3}{|c|}{$\begin{array}{c}\text { Male teachers }^{* *} \\
\text { Stage } \\
\text { of professional career }\end{array}$}} & \multirow{3}{*}{ Total } \\
\hline & & & & & & & & \\
\hline & I and II & III & IV & & I and II & III & IV & \\
\hline Friendly & 12 & 24 & 13 & 49 & 7 & 27 & 36 & 70 \\
\hline Favouring & 6 & 26 & 17 & 49 & 4 & 11 & 13 & 28 \\
\hline Unfriendly & 0 & 0 & 2 & 2 & 0 & 1 & 1 & 2 \\
\hline
\end{tabular}

Explications: I - "trainee” teacher, II - "contract” teacher, III - "qualified” teacher, IV - "certified" teacher, * $X^{2}=7.78 \mathrm{p}>0.05,{ }^{*} \mathrm{X}^{2}=1.59 \mathrm{p}>0.05$.

An important factor, deciding as to the introduction of optimal atmosphere during teaching of motor skills, is the style of conducting the lesson. It has been shown that the democratic style was utilised more frequently during teaching of motor skills than the autocratic style $(60 \%$ and $40 \%$ of the observed lessons, respectively). The democratic style was presented by "qualified" (39\%), "certified" (16\%), as well as "trainee" and "contract" female teachers. Among men, the democratic style was applied mainly by "certified", "qualified" and "trainee" teachers $(26 \%, 23 \%$ and $6 \%$, respectively). The autocratic style was observed at lessons conducted by men (45\%) and women (33\%) (tab. 2). The analysis of the style of conducting the group has shown a statistically significant relationship. 
Table 2. Predominant style of teaching (in \% of lessons)

\begin{tabular}{|c|c|c|c|c|c|c|c|c|}
\hline \multirow{3}{*}{$\begin{array}{l}\text { Categories } \\
\text { of responses }\end{array}$} & \multirow{2}{*}{\multicolumn{3}{|c|}{$\begin{array}{c}\text { Female teachers* } \\
\text { Stage } \\
\text { f professional career }\end{array}$}} & \multirow{3}{*}{ Total } & \multirow{2}{*}{\multicolumn{3}{|c|}{$\begin{array}{c}\text { Male teachers }{ }^{* *} \\
\text { Stage } \\
\text { of professional career }\end{array}$}} & \multirow{3}{*}{ Total } \\
\hline & & & & & & & & \\
\hline & I and II & III & IV & & \begin{tabular}{|l|} 
I and II \\
\end{tabular} & III & IV & \\
\hline Demo & 12 & 39 & 16 & 67 & 6 & 26 & 23 & 55 \\
\hline Autocratic & 5 & 11 & 17 & 33 & 6 & 13 & 26 & 45 \\
\hline
\end{tabular}

Explications: I - "trainee" teacher, II - "contract" teacher, III - "qualified" teacher, IV - "certified" teacher, * $X^{2}=19.12 \mathrm{p}<0.001,{ }^{*}{ }^{2} \mathrm{X}^{2}=45.61 \mathrm{p}<0.001$.

Among the indicatory, control, correcting and pro-social activities, such issues were analysed as: paying good attention during teaching on weak students, assessment of teaching, giving additional explanations, correcting of the taught movement, and satisfaction of the students after the completed lesson. The teachers helped weaker students while performing exercises in $75 \%$ of the lessons. Only occasionally such students were given help (during 65 lessons), which constitutes $21 \%$ of the analysed material. $4 \%$ of the lessons was conducted without offering assistance for the weak students while performing exercises. "Qualified" female teachers (36\%) and their male peers of the highest level of professional career $(37 \%)$ were the most eager in assisting the weaker students. Parallelly, it was noticed that $5 \%$ of the "qualified" and "certified" male teachers did not serve such help (tab. 3). The differences were statistically significant among men and not among women.

Table 3. Assisting weaker students during exercises (in \% of lessons)

\begin{tabular}{|c|c|c|c|c|c|c|c|c|}
\hline \multirow{3}{*}{$\begin{array}{l}\text { Categories } \\
\text { of responses }\end{array}$} & \multirow{2}{*}{\multicolumn{3}{|c|}{$\begin{array}{c}\text { Female teachers* } \\
\text { Stage } \\
\text { of professional career }\end{array}$}} & \multirow{3}{*}{ Total } & \multirow{2}{*}{\multicolumn{3}{|c|}{$\begin{array}{c}\text { Male teachers }^{* *} \\
\text { Stage } \\
\text { of professional career }\end{array}$}} & \multirow{3}{*}{ Total } \\
\hline & & & & & & & & \\
\hline & I and II & III & IV & & I and II & III & IV & \\
\hline Yes & 15 & 36 & 28 & 79 & 10 & 25 & 37 & 72 \\
\hline No & 0 & 2 & 0 & 2 & 1 & 3 & 12 & 6 \\
\hline Occasionally & 2 & 12 & 5 & 19 & 0 & 12 & 10 & 22 \\
\hline
\end{tabular}

Explications: I - "trainee” teacher, II - "contract” teacher, III - "qualified” teacher, IV - "certified" teacher, * $X^{2}=4.14 \mathrm{p}>0.05,{ }^{*}{ }^{2}=9.51 \mathrm{p}<0.05$.

The studied lessons were scored as very good (28\%), good $(60 \%)$, and satisfactory (12\%).

If we analyse the results according to gender of the teachers, we will achieve similar distribution of scores. Male teachers achieved $28 \%, 58 \%$ and $14 \%$ of the very good, good and satisfactory scores, respectively. In the same manner, female teachers achieved $26 \%, 61 \%$ and $13 \%$ of the very good, good and satisfactory scores. The groups formed through the different levels of the career showed similar distribution (tab. 4). In opposition to the lessons conducted by men, the lessons conducted by women did not show statistically significant differences in this aspect.
Table 4. Evaluation of teaching (in \% of lessons)

\begin{tabular}{|c|c|c|c|c|c|c|c|c|}
\hline \multirow{3}{*}{$\begin{array}{l}\text { Categories } \\
\text { of responses }\end{array}$} & \multirow{2}{*}{\multicolumn{3}{|c|}{$\begin{array}{c}\text { Female teachers* } \\
\text { Stage } \\
\text { of professional career }\end{array}$}} & \multirow{3}{*}{ Total } & \multirow{2}{*}{\multicolumn{3}{|c|}{$\begin{array}{c}\text { Male teachers }^{* *} \\
\text { Stage } \\
\text { of professional career }\end{array}$}} & \multirow{3}{*}{ Total } \\
\hline & & & & & & & & \\
\hline & I and II & III & IV & & I and II & III & IV & \\
\hline Very good & 7 & 12 & 7 & 26 & 3 & 9 & 16 & 28 \\
\hline Good & 7 & 31 & 23 & 61 & 6 & 24 & 28 & 58 \\
\hline Satisfactory & 3 & 7 & 3 & 13 & 3 & 6 & 5 & 14 \\
\hline
\end{tabular}

Explications: I - "trainee” teacher, II - “contract” teacher, III - "qualified” teacher, IV - "certified" teacher, * $X^{2}=5.91 \mathrm{p}>0.05,{ }^{*}{ }^{*} X^{2}=10.63 \mathrm{p}<0.05$

Providing additional explanations and correcting the movement being taught was considerably more frequently observed during the exercise $-70 \%$ of the assessed lessons, than after completing the exercise $-30 \%$ of the observed lessons. The additional explanations and correcting of the inaccuracies were more frequently provided by "qualified" female (29\%), and "certified" male (39\%) teachers. In contrast, explanations and correcting after completing the task were preferred by "qualified" female teachers (21\%) and their male peers at the same stage of the career (14\%) (tab. 5). Regardless of the gender of the persons conducting the classes, the statistical relationship was significant at the level of $\mathrm{p}<0.001$.

Table 5. Providing additional explanations and correcting of the movement being taught (in \% of lessons)

\begin{tabular}{|c|c|c|c|c|c|c|c|c|}
\hline \multirow{3}{*}{$\begin{array}{l}\text { Categories } \\
\text { of responses }\end{array}$} & \multirow{2}{*}{\multicolumn{3}{|c|}{$\begin{array}{c}\text { Female teachers* } \\
\text { Stage } \\
\text { of professional career }\end{array}$}} & \multirow{3}{*}{ Total } & \multirow{2}{*}{\multicolumn{3}{|c|}{$\begin{array}{c}\text { Male teachers ** } \\
\text { Stage } \\
\text { f professional career }\end{array}$}} & \multirow{3}{*}{ Total } \\
\hline & & & & & & & & \\
\hline & I and II & III & IV & & I and II & III & IV & \\
\hline During $\mathrm{tl}$ & 11 & 29 & 25 & 65 & 8 & 26 & 39 & 73 \\
\hline After the exercise & 6 & 21 & 8 & 35 & 2 & 14 & 11 & 27 \\
\hline
\end{tabular}

Explications: I - "trainee” teacher, II - "contract” teacher, III - "qualified” teacher, IV - "certified" teacher, " $X^{2}=21.9 \mathrm{p}<0.001,{ }^{*}{ }^{*} X^{2}=72.04 \mathrm{p}<0.001$.

$79 \%$ of the lessons led to the state of satisfaction in the students, while $21 \%$ of the lessons did not exert any emotions and the students were neutral after the lesson. The greatest number of satisfied students was found with the "certified" male $(44 \%)$ and "qualified" female (33\%) teachers. Conversely, the majority of the neutral students was found with the "qualified" male teachers $(11 \%)$ and their female colleagues at the same stage of the career (17\%) (tab. 6). A statistical significance at the level of $\mathrm{p}<0.05$ was found regarding the assessment of the satisfaction among the students after the lessons, regardless of the gender of the teachers conducting the lessons.

Table 6. Satisfaction of the students after completion of the lesson

\begin{tabular}{|c|c|c|c|c|c|c|c|c|}
\hline \multirow{3}{*}{$\begin{array}{l}\text { Categories } \\
\text { of responses }\end{array}$} & \multirow{2}{*}{\multicolumn{3}{|c|}{$\begin{array}{c}\text { Female teachers* } \\
\text { Stage } \\
\text { f professional career } \\
\end{array}$}} & \multirow{3}{*}{ Total } & \multirow{2}{*}{\multicolumn{3}{|c|}{$\begin{array}{c}\text { Male teachers** } \\
\text { Stage } \\
\text { of professional career }\end{array}$}} & \multirow{3}{*}{ Total } \\
\hline & & & & & & & & \\
\hline & I and II & III & IV & & I and II & III & IV & \\
\hline Satisfied & 13 & 33 & 29 & 75 & 9 & 28 & 44 & 81 \\
\hline Dissatisfied & 0 & 0 & 1 & 1 & 0 & 0 & 0 & 0 \\
\hline Neutral & 4 & 17 & 3 & 24 & 2 & 11 & 6 & 19 \\
\hline
\end{tabular}

Explications: I - "trainee” teacher, II - "contract” teacher, III - "qualified” teacher, IV - "certified" teacher, ${ }^{*} X^{2}=10.24 \mathrm{p}<0.05$, * ${ }^{*}{ }^{2}=7.52 \mathrm{p}<0.05$. 


\section{Discussion}

The subject of effective and lasting development of motor skills in the school process of physical education is a crucial task for every teacher, but correspondingly a different one, which especially should be known to teachers working at the last phase of education. Basing on the available knowledge from many disciplines of science, we can assume that teaching motor skills requires a precise analysis of the technique of movement and, among others, distinguishing its parts, sequence and mutual connections [5, 14]. That is the completion of the particular actions of a teacher, which is the exchange of information happening between the teacher and the student. The teaching of motor skills is in similar way understood by Czabański, according to whom that is "a sensory reception from the environment and mental transforming of the information regarding previously unknown motor action, and subsequently performing the action by means of the motor system and confirming the effectiveness of the action in various situations of the environment" [15]. Oppositely, Osiński claims that "teaching motor actions requires a proper sequence in the conduct of those actions:

- providing an accepted name of the exercise and its meaning and potentiality of utilising in sport, recreation or simply in life,

- a concise description of rules of actions, for the activation of mental processes and achievement of proper imagination about the structure of a given motor task, and for the preparation of an accurate reception of the demonstration,

- a model demonstration of an exercise,

- a mental analysis and confrontation of the imagination of the movement with the learned (during the demonstration) picture,

- performing the task under the supervision, with additional verbal and visual information from the teacher,

- stepwise and systematic progress to relatively independent conduct of the exercise in the more and more sophisticated authentic conditions" [3].

The results of our study have confirmed the correct conduct of all the assessed teachers' actions in terms of teaching motor skills. As for the preparatory actions, it has been found that the teaching was conducted in a friendly and favourable atmosphere, and the democratic style was more frequently used (60\%) than the autocratic style of teaching (40\%).

The indicative actions, when the teachers offered, during performing the exercises, assistance to the weaker students, have been positively assessed.

The effects of teaching in relation to the highest number of teachers, were scored as good, a few less teachers were graded with the mark very good, and the least number of teachers with the mark satisfactory.

Providing additional explanations and correcting the faults appeared more often while performing the exercises, than after completion of the tasks.

The final aspect of our study was the assessment of the conduct of the pro-social actions, related to the state of satisfaction of the students. According to the observers, the students were satisfied after completion of the majority of the lessons. The highest percentage of the responses "neutral" was found about the lessons conducted by the "qualified" male teachers.

\section{Conclusions}

1. The teachers, regardless their gender and stage of professional development, generally correctly and well conducted the teachers' actions related to the teaching of motor skills.

2. When conducting the preparatory actions, the teachers took care of a friendly and favourable atmosphere during teaching of movements Those actions were in majority accompanied by the democratic style (60\%), rather than the autocratic style (40\%), mainly preferred by the teachers of the "certified" stage of professional career.

3. During teaching of movements, the teachers assisted the weaker students, offered additional explanations and corrected inaccuracies while exercises were performed.

4. $60 \%$ of the teachers were graded with the mark good for the effects of teaching, a few less with the mark very good $(28 \%)$ and the least number of teachers with the mark satisfactory (12\%).

\section{Acknowledgements}

The research accomplished within the framework of research project of the Faculty of Physical Education and Sport in Biała Podlaska, Józef Piłsudski University of Physical Education in Warsaw - DS.104 - financed by the Ministry of Science and Higher Education.

\section{Literature}

1. Gałecki J., Zaradkiewicz T., Kurpeta L., Bergier B. (2011). Activities of physical education teachers in the process of forming motor skills of the students. Polish Journal of Sport and Tourism 18(1), 39-44.

2. Srokosz W. (1993). Psychosocial circumstances of the physical education teacher's activities of a lesson. In Z. Żukowska (Ed.), Towards the identity of the pedagogy of physical culture (pp. 73-76). Warszawa. PTNKF. [in Polish]

3. Osiński W. (2003). Kinesiology. Poznań: AWF Poznań. [in Polish]

4. Poplucz J. (1978). The system of the activities of the teacher. Warszawa: WSiP. [in Polish]

5. Strzyżewski S. (1996). The process of teaching and educating in physical culture. Warszawa: WSiP. [in Polish]

6. Tomaszewski T. (Ed.) (1978). Psychology. Warszawa: PWN. [in Polish]

7. Maszczak T. (Ed.) (2007). Physical education in the new school. Warszawa: Wydawnictwa Dydaktyczne. [in Polish]

8. Sulisz S. (1991). Physical education in primary school. Warszawa. WSiP. [in Polish]

9. Umiastowska D. (1998). The lesson of physical education. Szczecin: Uniwersytet Szczeciński. [in Polish]

10. Bielski J. (2000). Theoretical and methodological basis of the effectiveness of the teacher's occupation. Piotrków Trybunalski: Publishing House of WSP in Piotrków Trybunalski. [in Polish]

11. Janowski A. (1974). Educational guiding in the course of the lesson. Warszawa: WSiP. [in Polish]

12. Madejski E., Węglarz J. (2013). Wybrane zagadnienia wspótczesnej metodyki wychowania fizycznego. Kraków: Impuls. [in Polish]

13. Bielski J. (2012). Key problems of the theory of physical education. Kraków: Impuls. [in Polish]

14. Czabański B. (1980). The model of learning and teaching of sports motor actions. Wrocław: AWF Wrocław. [in Polish]

15. Czabański B. (1989). Selected aspects of learning and teaching of sports technique. Wrocław: AWF Wrocław. [in Polish]

Submitted:December 17, 2013

Accepted: January 20, 2014 